\title{
Ground Vegetation Survey for Xylella fastidiosa in California Almond Orchards
}

\author{
Elaine B. Shapland, Kent M. Daane, Glenn Y. Yokota, and Christina Wistrom, Department of Environmental \\ Science, Policy and Management, University of California, Berkeley 94720-3114; Joseph H. Connell, University of \\ California Cooperative Extension, Oroville 95965; Roger A. Duncan, University of California Cooperative Exten- \\ sion, Modesto 95358; and Mario A. Viveros, University of California Cooperative Extension, Bakersfield 93307
}

\begin{abstract}
Shapland, E. B., Daane, K. M., Yokota, G. Y., Wistrom, C., Connell, J. H., Duncan, R. A., and Viveros, M. A. 2006. Ground vegetation survey for Xylella fastidiosa in California almond orchards. Plant Dis. 90:905-909.

Xylella fastidiosa is a xylem-limited bacterium that causes almond leaf scorch (ALS), Pierce's disease of grapevines, and other plant diseases. We surveyed ground vegetation in ALS-infected almond orchards in California's Central Valley for the presence of this bacterium. Plant tissue samples were collected throughout a 2-year period and processed for the presence of X. fastidiosa using restriction enzyme digestion of RST31 and RST33 polymerase chain reaction (PCR) products and bacterial culture on selective media. Overall disease incidence was low in the ground vegetation species; only 63 of 1,369 samples tested positive. Of the 38 species of common ground vegetation tested, 11 tested positive for $X$. fastidiosa, including such common species as shepherd's purse (Capsella bursa-pastoris), filaree (Erodium spp.), cheeseweed (Malva parvifolia), burclover (Medicago polymorpha), annual bluegrass (Роа аппиа) London rocket (Sisymbrium irio), and chickweed (Stellaria media). There was a seasonal component to bacterial presence, with positive samples found only between November and March. Both ground vegetation and almond trees were most commonly infected with the almond strain of $X$. fastidiosa (six of seven surveyed sites). ALS-infected almond samples had an X. fastidiosa concentration within previously reported ranges $\left(1.84 \times 10^{6}\right.$ to $\left.2.15 \times 10^{7} \mathrm{CFU} / \mathrm{g}\right)$; however, we were unable to accurately measure $X$. fastidiosa titer in sampled ground vegetation for comparison. These results are discussed with respect to ground vegetation management for ALS control.
\end{abstract}

Additional keywords: blue-green sharpshooter, glassy-winged sharpshooter, green sharpshooter

Pierce's disease (PD) of grape and almond leaf scorch (ALS) threaten the profitable production of these crops in California. Both diseases are caused by the xylem-limited bacterium Xylella fastidiosa $(7,22,34)$. Leaf damage occurs when the bacteria grow to such high concentrations that water and nutrient transport systems become occluded, leading to water stress in the leaves $(24,33)$. Leaf and stem damage can progressively worsen until photosynthesis and nutrient production are impaired, thus lowering the quality and quantity of fruit produced and, eventually, killing susceptible grape or almond cultivars (23). X. fastidiosa is also the causal agent of diseases in other crops, including citrus variegated chlorosis, oleander leaf scorch, plum leaf scald, alfalfa dwarf, and phony peach $(4,28,31,35)$.

In California, much research has been conducted on the epidemiology of PD. Early surveys for the causal agent deter-

Corresponding author: K. Daane

E-mail: daane@uckac.edu

Accepted for publication 17 February 2006.

DOI: 10.1094/PD-90-0905

(C) 2006 The American Phytopathological Society mined that the pathogen was spread by xylem-feeding sharpshooters, such as the blue-green sharpshooter (Graphocephala atropunctata; 12,15). Subsequent studies confirmed that xylem-feeding hemipterans acquire and transmit $X$. fastidiosa via their normal feeding on the xylem tissues (18). More recent studies focused on PD epidemiology as influenced by the glassywinged sharpshooter (GWSS), Homalodisca coagulata (Say) (32). Many plants used by insect vectors as feeding and breeding hosts also can harbor X. fastidiosa. Surveys of vegetation in and near vineyards with $\mathrm{PD}$ in northern California and Florida found $X$. fastidiosa in numerous asymptomatic plants $(6,19,25,30)$. Similar surveys for the bacteria in plants growing near citrus groves with citrus variegated chlorosis have been conducted in Brazil (20).

PD and ALS disease development requires more than the presence of susceptible crop cultivars, insect vectors, and plant species which are suitable for vector feeding or breeding. After $X$. fastidiosa is inoculated into a host plant, bacterial multiplication, systemic movement, and expression of disease symptoms depends on many factors, including the temperature (10), date of infection (9), and the X. fastidiosa strain $(2,13)$. We hypothesize that a reservoir population of $X$. fastidiosa can reside in other plants near grape or almond orchards without the outward expression of plant disease. X. fastidiosa reservoirs in adjacent vegetation may increase the likelihood that nearby susceptible crops will become infected. Removal of blue-green sharpshooter breeding hosts was a proposed method for controlling the spread of $\mathrm{PD}$ in California's coastal wine grape regions (27). As yet, there have not been similar studies of vegetation management for controlling the spread of ALS, which has been increasing in prevalence and severity in California's interior valleys. By identifying the seasonal presence and incidence of $X$. fastidiosa in common ground vegetation in or near almond orchards, weed control efforts can be appended to reduce reservoir $X$. fastidiosa host species and reduce the level of bacterial inoculum.

The purpose of this study was to (i) survey vegetation in northern and central California almond orchards to identify the plant species present throughout the season; (ii) determine the presence or absence, concentration, and strain of $X$. fastidiosa in the sampled ground vegetation; and (iii) to record the disease incidence and $X$. fastidiosa strain in almond trees near harvest time.

\section{MATERIALS AND METHODS}

Ground vegetation survey. Sample sites were selected based on grower reports of ALS incidence. Surveyed orchards were located in the north Central Valley (approximately $121^{\circ} 55^{\prime} \mathrm{W}, 36^{\circ} 36^{\prime} \mathrm{N}$, Butte County; approximately $122^{\circ} 09^{\prime} \mathrm{W}, 39^{\circ} 39^{\prime} \mathrm{N}$, Glenn County), the middle of the Central Valley (approximately $121^{\circ} 03^{\prime} \mathrm{W}, 37^{\circ} 31^{\prime} \mathrm{N}$ and approximately $120^{\circ} 44^{\prime} \mathrm{W}, 37^{\circ} 39^{\prime} \mathrm{N}$, Stanislaus County), and the south Central Valley (approximately $119^{\circ} 17^{\prime} \mathrm{W}, 35^{\circ} 22^{\prime} \mathrm{N}$ and approximately $119^{\circ} 15^{\prime} \mathrm{W}, 35^{\circ} 20^{\prime} \mathrm{N}$, Kern County). Vegetation was collected every 2 to 6 weeks, depending on seasonal abundance. On each visit, researchers walked through the orchard and conducted a visual survey for the four most abundant weed species. Vegetation was identified according to the Statewide Integrated Pest Management Program produced by the Agriculture and Natural Resources Department at the University of California, Davis (available online). Four evenly spaced rows then were selected (300 to $400 \mathrm{~m}$ per row) and three to five leaves of 
each of the common weed species were collected from each transect. Samples were stored separately for each species and transect in a 3.8-liter plastic bag. In all, 10 to 30 individual plants were sampled for each weed species in each transect. The material was stored in a cooler (approximately $7^{\circ} \mathrm{C}$ ) and processed for $X$. fastidiosa presence within 2 days of collection.

Bacterial detection and strain identification. Each sample (plant species and transect) was processed separately for the presence of $X$. fastidiosa. We selected plant parts where sharpshooters were known to feed, such as leaf petioles, leaf blade bases of grasses, and plant stems $(11,18)$. The samples were assayed for the presence of $X$. fastidiosa using immunocapture DNA separation and polymerase chain reaction (PCR) amplification with primers RST31

Table 1. Ground vegetation collected from almond orchards and processed for the presence of Xylella fastidiosa using immunocapture DNA extraction and polymerase chain reaction

\begin{tabular}{|c|c|c|c|c|}
\hline \multirow[b]{2}{*}{ Scientific name } & \multirow[b]{2}{*}{ Common name } & \multicolumn{2}{|c|}{ X. fastidiosa } & \multirow[b]{2}{*}{ Reference $^{z}$} \\
\hline & & This study & Previous studies & \\
\hline \multirow{2}{*}{ Amaranthus spp. } & Pigweed & - & - & 6 \\
\hline & & $\ldots$ & + & $36 *$ \\
\hline Amsinckia spp. & Fiddleneck & - & - & 6 \\
\hline Anagallis arvensis & Scarlet pimpernel & - & - & 6 \\
\hline Avena fatua & Wild oat & - & + & 11 \\
\hline Brassicaceae spp. & Mustards & - & + & 6 \\
\hline Capsella bursa-pastoris & Shepherd's purse & + & N/A & $\ldots$ \\
\hline Chamaesyce maculata & Spotted spurge & - & N/A & $\ldots$ \\
\hline Chamomilla suaveolens & Pineapple weed & - & N/A & $\ldots$ \\
\hline Chenopodium album & Lambsquarter & - & N/A & $\ldots$ \\
\hline Claytonia perfoliata & Miner's lettuce & - & + & 30,31 \\
\hline Conyza bonariensis & Fleabane & - & N/A & $\ldots$ \\
\hline Conyza canadiensus & Horseweed & - & + & $36^{*}$ \\
\hline Coronopus didymus & Lesser swinecress & - & N/A & $\ldots$ \\
\hline Cyperus esculentus & Yellow nutsedge & - & + & 11 \\
\hline \multirow[t]{2}{*}{ Echinochloa crus-galli } & Barnyard grass & - & + & $17^{*}$ \\
\hline & & $\ldots$ & + & $36 *$ \\
\hline \multirow[t]{3}{*}{ Erodium spp. } & Filaree & + & + & $11^{*}$ \\
\hline & & $\ldots$ & + & $36^{*}$ \\
\hline & & $\ldots$ & - & 6 \\
\hline Escallonia montevidensis & Escallonia & - & + & 11 \\
\hline Festuca spp. & Fescue grass & - & N/A & $\ldots$ \\
\hline Helianthus spp. & Sunflower & - & + & $6^{*}$ \\
\hline Hordeum murinium & Hare barley & - & + & 11 \\
\hline \multirow[t]{2}{*}{ Lactuca serriola } & Prickly lettuce & - & - & 30,31 \\
\hline & & $\ldots$ & + & $36^{*}$ \\
\hline \multirow[t]{2}{*}{ Malva parvifolia } & Cheeseweed & + & - & 6 \\
\hline & & $\ldots$ & _- & $11 *$ \\
\hline Medicago polymorpha & Burclover & + & + & 11 \\
\hline Роа аппиа & Annual bluegrass & + & + & 11 \\
\hline \multirow[t]{2}{*}{ Portulaca oleracea } & Common purslane & - & - & $11^{*}$ \\
\hline & & $\ldots$ & + & $36^{*}$ \\
\hline Ranunculus spp. & Buttercup & - & N/A & $\ldots$ \\
\hline Rumex crispus & Curly dock & - & + & 11 \\
\hline Salsola tragus & Russian thistle & - & N/A & $\ldots$ \\
\hline Senecio vulgaris & Common groundsel & + & N/A & $\ldots$ \\
\hline Sisymbrium irio & London rocket & + & N/A & $\cdots$ \\
\hline Sonchus oleraceus & Annual sowthistle & - & + & $36 *$ \\
\hline Sonchus spp. & Sowthistle & + & - & 6 \\
\hline \multirow[t]{2}{*}{ Sorghum halepense } & Johnsongrass & - & + & $11^{*}$ \\
\hline & & $\ldots$ & - & 30,31 \\
\hline Stellaria media & Chickweed & + & N/A & $\ldots$ \\
\hline Typha spp. & Cat tail & - & N/A & $\ldots$ \\
\hline Urtica urens & Burning nettle & + & N/A & $\ldots$ \\
\hline Veronica persica & Speedwell & + & N/A & $\ldots$ \\
\hline Xanthium strumarium & Cocklebur & _- & + & $36^{*}$ \\
\hline
\end{tabular}

${ }^{\mathrm{z}}$ Results are compared against previous field surveys near vineyards and riparian areas, except for references marked with an asterisk (*), which refer to greenhouse studies.
$1 / 1,000$ in PBS/BSA) was added to each sample. Samples were incubated at room temperature for $30 \mathrm{~min}$ with gentle shaking, followed by centrifugation at $14,000 \times$ $g$ for $2.5 \mathrm{~min}$. The pellet then was resuspended in $1.0 \mathrm{ml}$ of PBS/BSA, centrifuged a second time for $2.5 \mathrm{~min}$, and resuspended in $1.0 \mathrm{ml}$ of PBS/BSA. Five $\mu \mathrm{l}$ of Dynabeads M-280 sheep anti-rabbit immunoglobulin G (Dynal Biotech, Lake Success, NY) was added to each sample and incubated at room temperature for 30 min with gentle shaking. The magnets then were removed with a Magnetic Particle Concentrator (Dynal MPC-S, Oslo), and washed three times with $1.0 \mathrm{ml}, 1.0 \mathrm{ml}$, and $500 \mu \mathrm{l}$ of PBS/BSA. Finally, the beadantibody-bacteria complex was resuspended in $10 \mu \mathrm{l}$ of sterile distilled water (B. Kirkpatrick, unpublished).

For PCR amplification, all samples were prepared in sterile 0.6- $\mathrm{ml}$ microcentrifuge tubes with $12.5 \mu \mathrm{l}$ of Taq Master Mix (Qiagen, Valencia, CA), 6.5 $\mu$ l of PCR water, $1 \mu \mathrm{l}$ of each primer (RST-31 and RST-33), and $4 \mu \mathrm{l}$ of DNA extract. PCR reactions were carried out in a Thermal Cycler according to the conditions described by Minsavage, et al. (21). PCR products were separated by electrophoresis in $1.5 \%$ agarose gel, stained with ethidium bromide, and viewed under ultraviolet light. The presence of $X$. fastidiosa in the original sample was determined by a band at $733 \mathrm{~kb}(21)$.

After gel electrophoresis, a preliminary strain difference analysis was carried out according to Hendson et al. (14). The PCR product from all positive samples was subjected to restriction enzyme digestion with Rsa1 (10 $\mu$ l of PCR product, $0.2 \mu$ of Rsa1, $0.2 \mu \mathrm{l}$ of BSA, $2.0 \mu \mathrm{l}$ of buffer C, and $7.6 \mu \mathrm{l}$ of water) at $37^{\circ} \mathrm{C}$ for $2 \mathrm{~h}$. The RST31 and RST33 PCR products from $X$. fastidiosa strains of oak, oleander, peach, plum, and all but three ALS strains were cleaved into two fragments of about 233 and $500 \mathrm{bp}$, whereas the PCR products from all PD strains as well as the ALS strains ALS1, Manteca, and Tulare were not digested by Rsa1 (14).

Bacterial titer and incidence. Attempts were made to culture $X$. fastidiosa from symptomatic almond trees at each site and from fresh samples of alternate host plants at sites where previously collected samples tested positive for $X$. fastidiosa, using immunocapture DNA separation and PCR amplification. In late summer and early fall, when the symptoms of ALS were most obvious, we surveyed each orchard and collected symptomatic almond leaf and petiole samples. Both ground vegetation and almond samples were processed for bacterial culture on selective media within $24 \mathrm{~h}$. We plated samples on both periwinkle wilt (PWG) and Pierce's disease-3 (PD3) media to provide a rudimentary indication of $X$. fastidiosa strain; grape strains of $X$. fastidiosa grow on both 
PWG (16) and PD3 (8), but some almond strains grow only on PWG (2). Samples were prepared for culture according to procedures described by Hill and Purcell (17) in order to determine both the strain and concentration of bacteria in almond and ground vegetation samples.

Data analysis. Data were analyzed by determining CFU per gram of plant material, with averages compared using analysis of variance, and means separated using Tukey's honestly significant difference comparison.

\section{RESULTS}

Ground vegetation survey. From June 2003 to April 2005, 58 collections were made during 10 trips. Thirty-eight species of ground vegetation were commonly found (Table 1), with most material collected in winter and spring when ground vegetation was abundant. Between August and October, it was difficult to find live ground vegetation within the almond or- chards, because standard management practices required the orchard floor to be completely free of vegetation prior to harvest in August. Irrigation is discontinued, so that the nuts can be shaken from the trees and dried on the bare ground. All orchards in this study followed these practices. As a result, at that time we often pooled samples across the orchard rows (transects) to produce a single sample for each plant species and orchard (Fig. 1, data from both years are combined).

Bacterial presence. Results for $X$. fastidiosa presence in vegetative ground cover species are presented as a qualitative "positive" or "negative" to express the potential role of these plant species as alternative hosts. Of 1,369 samples from the six orchards, 63 were positive for $X$. fastidiosa (4.6\%). X. fastidiosa was recovered from 11 of the 38 ground vegetation plant species, including Capsella bursapastoris (shepherd's purse), Malva parvifolia (cheeseweed), Senecio vulgaris (common groundsel), Sisymbrium irio (London rocket), Sonchus spp. (sowthistle), Stellaria media (chickweed), Urtica urens (burning nettle), Veronica persica (speedwell), 8 species from which it had not previously been recovered in the field (Table 1). There was a strong seasonal component to bacterial presence in ground vegetation, with no $X$. fastidiosa-positive samples found between April and midOctober during the two years of the study (Table 2). Linear regression shows that there was a positive and significant relationship between the number of samples taken per plant species and the percentage of samples positive for $X$. fastidiosa $(y=$ $0.0553 x-0.2074, R^{2}=0.8935$ ).

Bacterial presence and strain. Results from the restriction enzyme digestion of PCR products with $R s a 1$ and the bacterial culture on selective media showed that almond trees in six of seven experimental orchards were infected with the almond strain of $X$. fastidiosa. At one site (Zeering

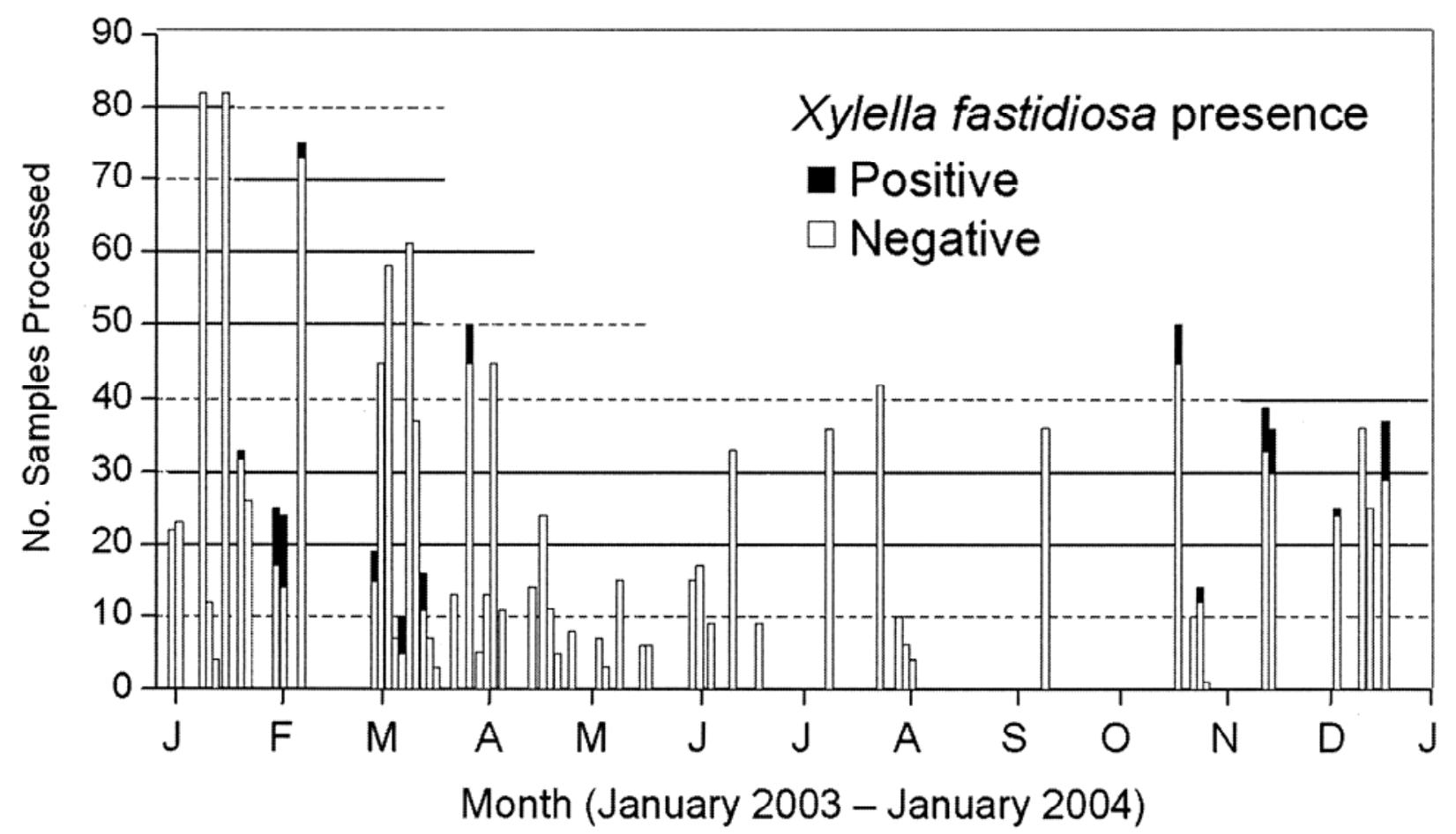

Fig. 1. Survey of vegetation in almond orchards for Xylella fastidiosa. Data show combined results from six almond orchards in Butte, Glenn, Stanislaus, and Kern Counties from June 2003 to April 2005.

Table 2. Ground vegetation found to be positive for the presence of Xylella fastidios $a^{z}$

\begin{tabular}{|c|c|c|c|c|c|c|c|c|c|c|c|c|}
\hline Vegetation & January & February & March & April & May & June & July & August & September & October & November & December \\
\hline Burning nettle & $\ldots$ & $\square$ & $\ldots$ & $\ldots$ & $\ldots$ & $\ldots$ & $\ldots$ & $\ldots$ & $\ldots$ & $\ldots$ & $\ldots$ & $\ldots$ \\
\hline Common groundsel & $\ldots$ & $\ldots$ & $\ldots$ & $\ldots$ & $\ldots$ & $\ldots$ & $\ldots$ & $\ldots$ & $\ldots$ & $\ldots$ & a & $\ldots$ \\
\hline Speedwell & $\ldots$ & $\bullet$ & $\ldots$ & $\ldots$ & $\ldots$ & $\ldots$ & $\ldots$ & $\ldots$ & $\ldots$ & $\ldots$ & $\ldots$ & $\ldots$ \\
\hline Sowthistle & $\ldots$ & $\ldots$ & - & $\ldots$ & $\ldots$ & $\ldots$ & $\ldots$ & $\ldots$ & $\ldots$ & $\ldots$ & $\ldots$ & $\ldots$ \\
\hline London Rocket & $\ldots$ & घ & घ & $\ldots$ & $\ldots$ & $\ldots$ & $\ldots$ & $\ldots$ & $\ldots$ & $\ldots$ & $\ldots$ & $\ldots$ \\
\hline Annual bluegrass & $\ldots$ & $\ldots$ & - & $\ldots$ & $\ldots$ & $\ldots$ & $\ldots$ & $\ldots$ & $\ldots$ & $\begin{array}{l}\cdots \\
\ldots\end{array}$ & $\begin{array}{l}\cdots \\
\ldots\end{array}$ & ๑ \\
\hline Cheeseweed & $\diamond$ & $\ldots$ & 口 & $\ldots$ & $\ldots$ & $\ldots$ & $\ldots$ & $\ldots$ & $\ldots$ & $\diamond$ & घ & $\bullet \bullet$ \\
\hline Chickweed & $\ldots$ & $\bullet$ & $\bullet$ & $\ldots$ & 口 & $\ldots$ & $\ldots$ & $\ldots$ & $\ldots$ & $\ldots$ & $\bullet$ & - \\
\hline Burclover & $\ldots$ & $\ldots$ & $\bullet$ & $\ldots$ & $\ldots$ & $\ldots$ & $\ldots$ & $\ldots$ & $\ldots$ & $\ldots$ & $\ldots$ & $\ldots$ \\
\hline Shepherd's purse & $\ldots$ & - & $\bullet$ & $\ldots$ & घ & $\ldots$ & $\ldots$ & $\ldots$ & $\ldots$ & $\ldots$ & • & $\ldots$ \\
\hline Filaree & $\ldots$ & $\ldots$ & $\bullet \bullet$ & $\ldots$ & $\ldots$ & $\ldots$ & $\ldots$ & $\ldots$ & $\ldots$ & $\bullet$ & - & $\bullet$ \\
\hline
\end{tabular}

${ }^{\mathrm{z}}$ Data combined from six almond orchards, from June 2003 to April 2005; $\mathbf{\square}=$ Kern, $\bullet=$ Stanislaus, $\bullet=$ Butte, and $\boldsymbol{\bullet}=$ Glenn. 
Road in Stanislaus County), a grape strain of $X$. fastidiosa was isolated from all weeds and almond trees sampled (Table 3). At each site, tissue samples from both almond trees and surrounding weeds gave the same result: each contained either the grape or almond strain of $X$. fastidiosa, but never both. from ALS-infected almond trees at Zeering Road containing the grape strain of $X$. fastidiosa had an average concentration of $2.15 \times 10^{6} \mathrm{CFU} / \mathrm{g}$, which is significantly greater than the concentrations at other sites sampled $(P=0.014)$. Our results age $X$. fastidiosa titer in ALS-symptomatic almond leaves ( 3 ) is lower than the average $X$. fastidiosa titer in PD-symptomatic grape (18). All ground vegetation samples were contaminated with other bacteria so that $X$. fastidiosa presence could not be determined using culture techniques (results not shown). Previous researchers also have encountered this difficulty when attempting to culture $X$. fastidiosa from field samples $(20,36)$.

\section{DISCUSSION}

All previous field surveys for $X$. fastidiosa in alternate host plants have focused on PD management. With the recent increase of ALS in California, there was an even greater need to survey plants in almond orchards for $X$. fastidiosa. We showed the presence of $X$. fastidiosa grape and almond strains in $29.7 \%$ of the common ground vegetation species sampled. Numerous studies have documented the survival of $X$. fastidiosa in different plant species $(1,27,36)$; however, few studies have included field surveys $(6,19,29)$. This is the first reported survey for the seasonlong incidence of $X$. fastidiosa in nonsymptomatic host plants in almond orchards. In comparison, one of the first plant surveys examined the ability of insect vectors to transfer $X$. fastidiosa (at the time unknown) from symptomatic PDinfected grape plants to potential host plants and back to clean grape plants (11). Despite the broad range of host plants included in that survey, conclusions about disease transmission were made based
Bacteria titer and incidence. Petioles agree with previous findings that the aver-

solely on symptom development in grape. Subsequent studies showed that plants can harbor $X$. fastidiosa at concentrations high enough for insect acquisition and transmission without exhibiting symptoms of disease $(27,36)$. In addition, the symptoms of PD and alfalfa dwarf that Freitag (11) used as diagnostic can be misidentified as water or nutrient stress (22).

We used a sensitive detection method of immunocapture DNA separation followed by PCR to survey for $X$. fastidiosa in vegetation in almond orchards for 2 years. In an earlier field survey of riparian plants in the Napa River Valley, Raju et al. (29) found a number of perennial trees and shrubs and ground covers positive for the presence of $X$. fastidiosa, using enzyme-linked immunosorbent assay (ELISA) as a detection method. Costa et al. (6) also used ELISA as a detection method, due to its low cost and lower time investment than PCR, to screen large numbers of potential host plants for X. fastidiosa in vineyard ground covers. Although immunocapture DNA separation and PCR are more sensitive detection methods for finding $X$. fastidiosa in plant material than is ELISA (21), all established modern DNA detection methods are reliable for finding $X$. fastidiosa in plant material. Our survey results found $X$. fastidiosa in many of the same ground cover species as the Costa et al. (6) field survey and Wistrom and Purcell (36) glasshouse study (Table 1). In addition, we never recovered $X$. fastidiosa from a species that was negative for the bacterium in glasshouse studies, indicating that our study returned a low level of false positives.

The sampled habitat in our study (almond fields in the Central Valley) provided clear differences from the earlier surveys (vineyards and riparian areas). Similarities between almond and grape crops include winter dormancy, late summer harvest, and overlap in growing regions. However, different plant species are present near grape and almond crops, which could result in different patterns of disease spread. For example, sharpshooters often enter vineyards from adjacent riparian vegetation. This vegetation generally is unmanaged, left for wildlife habitat, stream bank stabi-

Table 3. Concentrations of Xylella fastidiosa found in almond trees with classical symptoms of almond leaf scorch (ALS) and in surrounding ground vegetation

\begin{tabular}{lccc}
\hline & \multicolumn{2}{c}{ Strain in } & \\
\cline { 2 - 3 } Site (county) & Almonds $^{\mathbf{y}}$ & Ground vegetation & \\
\hline Grainland Rd (Butte) & Almostidiosa titer $^{\mathbf{z}}$ \\
Anita Rd (Butte) & Almond & Almond & $1.84 \times 10^{6} \mathrm{ab}$ \\
Rd P (Glenn) & Almond & Almond & $2.30 \times 10^{6} \mathrm{~b}$ \\
Rd VV (Glenn) & $\ldots$ & Almond & $1.19 \times 10^{7} \mathrm{ab}$ \\
Zeering Rd (Stanislaus) & Grape & Almond & N/A \\
Tim Bell Rd (Stanislaus) & Almond & Grape & $2.15 \times 10^{7} \mathrm{a}$ \\
Site \#7 (Kern) & Almond & Almond & $6.27 \times 10^{6} \mathrm{~b}$ \\
\hline
\end{tabular}

y Results based on polymerase chain reaction and restriction enzyme digestion with $R s a 1$.

${ }^{\mathrm{z}}$ Average CFU/g cultured from ALS symptomatic petioles, 27 July and 14 October 2004. Different letters after each mean indicate a significance difference $(P<0.05)$, Tukey's pairwise comparison. lization, and an aesthetic resource. In contrast, in midsummer the almond floor is stripped of all vegetation in preparation for the August harvest. The trees are shaken to drop the nuts onto the ground, where they dry in the sun for 2 weeks before being collected with a vacuum. Other differences arise from the shape and size of the crop plants. Grapevines are planted in discrete rows, where adjacent vines often intertwine. Insects of all types can easily travel from one plant to another, which may account for much of the observed vine-tovine spread in insect-vectored diseases of grape. Almond trees are planted in a grid pattern, with trunks separated by 3 to $6 \mathrm{~m}$. If adjacent plants touch, it is in the canopy, high off the ground and less accessible to any insect vectors feeding on ground vegetation. This arrangement could be one explanation of the lack of obvious tree-totree spread that we observed in the surveyed almond orchards (E. B. Shapland and K. M. Daane, unpublished).

Of the $X$. fastidiosa-positive plant species in our survey, 9 of the 11 were present in the orchards on most of the sampling dates and, thus, composed the largest sample sizes of all ground vegetation species. There also was a positive and significant relationship between the number of samples taken per plant species and the percentage of samples positive for $X$. fastidiosa. Potentially, these insect vectors are not selective about the plant species they fed upon and, therefore, frequently encounter the most common plant species, thus moving the bacterium among these plants. In addition, some of the less common plant species in our sampled orchards were common hosts of $X$. fastidiosa in other surveys, but were negative in our 2year survey (Table 1). Thus, the feeding behavior of these insects could be a more important factor in controlling the spread of ALS. We currently are conducting transmission tests in the greenhouse with green sharpshooters and the most frequently infected weed species.

Perhaps the most important feature in the relationship between ALS and resident ground vegetation is that we detected $X$. fastidiosa in weeds only during the cooler months, between October and April. This is in contrast to most previous field surveys that were conducted primarily during the growing season and in which $X$. fastidiosa was detected during the warmer summer months $(6,11,19)$. Seasonality and temperature are important for ALS or PD epidemiology because $X$. fastidiosa survives best in the plants at a moderate temperature (10) and plants inoculated late in the growing season may not develop chronic disease symptoms (35). We hypothesize that the ground vegetation in the surveyed orchards best harbored X. fastidiosa at temperatures that were most consistent during the winter months, and when these fall or winter ground covers 
were newly formed and in good condition. During the late spring and summer months, most ground vegetation in the almond orchard was small and in poor condition. These results suggest the need for further investigation about the correlation between seasonal presence and concentration of $X$. fastidios $a$ in ground covers and the seasonal presence and abundance of potential insect vectors. Unlike in vineyards, where a clear edge effect has been found with PD incidence (27), most previous work has not revealed any clear spatial patterns with ALS (26).

We found that the almond strain of $X$. fastidiosa was most common in the surveyed ALS-infected orchards. Recent studies on the biology of different strains of $X$. fastidiosa have shown varying abilities to infect different hosts: grape strains will cause disease symptoms in almond, grape (2), and oleander (28), but neither almond strains (2) nor oleander strains (28) will cause disease in grape. A recent study near Fresno, CA, showed that characteristics of different varietals of almond as well as strain type (almond or grape) result in differing severity of ALS (13). A parallel study found both the almond and grape genotypes of $X$. fastidiosa in the same plant, pointing out that the presence of a less virulent strain does not preclude the existence of a more virulent strain (5). We found significantly higher $X$. fastidiosa titers in almond petioles containing the grape strain compared with petioles with almond strain $X$. fastidiosa $(P<0.014)$. This is consistent with previous findings that grape strain colonizes almond petioles to a higher extent than can almond strain $X$. fastidiosa (2).

Our results showed that common ground vegetation can harbor $X$. fastidiosa on the almond floor. This suggests that a yearround weed control in the almond orchards may assist in management of $X$. fastidiosa.

\section{ACKNOWLEDGMENTS}

This research was supported by grants from the California Department of Food and Agriculture Pierce's Disease and Glassy-winged Sharpshooter Board, and the Almond Board of California. We thank A. Purcell for providing invaluable research advice, as well as laboratory space and equipment; L. J. Baker, M. Wilhelm, and M. Pryor for field and laboratory help; and C. M. Curley and K. R. Sime for providing comments on an earlier draft of this manuscript.

\section{LITERATURE CITED}

1. Almeida, R. P. P., and Pereira, E. F. 2001. Multiplication and movement of a citrus strain of Xylella fastidiosa within sweet orange. Plant Dis. 85:382-386.

2. Almeida, R. P. P., and Purcell, A. H. 2003. Biological traits of Xylella fastidiosa strains from grapes and almonds. Appl. Environ. Microbiol. 69:7447-7452.
3. Almeida, R. P. P., and Purcell, A. H. 2003. Homalodisca coagulata (Hemiptera, Cicadellidae) transmission of Xylella fastidiosa to almond. Plant Dis. 87:1255-1259.

4. Chang, C. J., Garnier, M., Zreik, L., Rossetti, V., and Bove, J. M. 1993. Culture and serological detection of the xylem-limited bacterium causing citrus variegated chlorosis and its identification as a strain of Xylella fastidiosa. Curr. Microbiol. 27:137-142.

5. Chen, J., Groves, R., Civerolo, E. L., Viveros, M., Freeman, M., and Zheng, Y. 2005. Two Xylella fastidiosa genotypes associated with almond leaf scorch disease on the same location in California. Phytopathology 95:708-714.

6. Costa, H. S., Raetz, E., and Pinckard, T. R. 2004. Plant hosts of Xylella fastidiosa in and near southern California vineyards. Plant Dis. 88:1255-1261.

7. Davis, M. J., Purcell, A. H., and Thompson, S. V. 1978. Pierce's disease of grapevines: isolation of the causal bacterium. Science 199:7577.

8. Davis, M. J., Whitcomb, R. F., and Gillaspie, A. G. J. 1981. Fastidious bacteria of plant vascular tissue and invertebrates (including socalled rickettsia-like bacteria). Pages 12301234 in: The Prokaryotes: A Handbook on Habits, Isolation, and Identification of Bacteria. M. P. Starr, H. Stolp, H. G. Truper, A. Balows, and H. G. Schlegel, eds. Springer-Verlag, Berlin, Heidelberg.

9. Feil, H., Feil, W. S., and Purcell, A. H. 2003. Effects of date of inoculation on the withinplant movement of Xylella fastidiosa and persistence of Pierce's disease within field grapevines. Phytopathology 93:244-251.

10. Feil, H., and Purcell, A. H. 2001. Temperaturedependent growth and survival of Xylella fastidiosa in vitro and in potted grapevines. Plant Dis. 85:1230-1234.

11. Freitag, J. H. 1951. Host range of the Pierce's disease virus of grapes as determined by insect transmission. Phytopathology 41:920-934.

12. Freitag, J. H., and Frazier, N. W. 1949. Natural infectivity of leafhopper vectors of Pierce's disease virus of grape in California. Phytopathology 44:7-11.

13. Groves, R. L., Chen, J., and Civerolo, E. L. 2005. Spatial analysis of almond leaf scorch disease in the San Joaquin Valley of California: factors affecting pathogen distribution and spread. Plant Dis. 89:581-589.

14. Hendson, M., Purcell, A. H., Chen, D., Smart, C., Guilhabert, M., and Kirkpatrick, B. 2001. Genetic diversity of Pierce's disease strains and other pathotypes of Xylella fastidiosa. Appl. Environ. Microbiol. 67:895-903.

15. Hewitt, W. B., Houston, B. R., Frazier, N. W., and Freitag, J. H. 1946. Leafhopper transmission of the virus causing Pierce's disease of grape and dwarf of alfalfa. Phytopathology 36:117-128.

16. Hill, B. L., and Purcell, A. H. 1995. Acquisition and retention of Xylella fastidiosa by an efficient vector, Graphocephala atropunctata. Phytopathology 85:209-212.

17. Hill, B. L., and Purcell, A. H. 1995. Multiplication and movement of Xylella fastidiosa within grapevine and four other pants. Phytopathology 85:1368-1372.

18. Hill, B. L., and Purcell, A. H. 1997. Populations of Xylella fastidiosa in plants required for transmission by an efficient vector. Phytopathology 87:1197-1201.

19. Hopkins, D. L., and Alderz, W. C. 1988. Natural hosts of Xylella fastidiosa in Florida. Plant
Dis. 72:429-431.

20. Lopes, S. A., Marcussi, S., Torres, S. C. Z., Souza, V., Fagan, C., and Franca, S. C. 2003. Weeds as alternative hosts of the citrus, coffee, and plum strains of Xylella fastidiosa in Brazil. Plant Dis. 87:544-549.

21. Minsavage, G. V., Thompson, C. M., Hopkins, D., Leite, R. M. B. V. C., and Stall, R. E. 1994 Development of a polymerase chain reaction protocol for detection of Xylella fastidiosa in plant tissue. Phytopathology 84:456-461.

22. Mircetich, S. M., Lowe, S. K., Moller, W. J. and Nyland, G. 1976. Etiology of almond leaf scorch disease and transmission of the causal agent. Phytopathology 66:17-24.

23. Moller, W. J., Sanborn, R. R., Mircetich, S. M., Williams, H. E., and Beutel, J. A. 1974. A newly recognized and serious leaf scorch disease of almond. Plant Dis. Rep. 58:99-101.

24. Newman, K. L., Almeida, R. P. P., Purcell, A. H., and Lindow, S. E. 2003. Use of a green fluorescent strain for analysis of Xylella fastidiosa colonization of Vitis vinifera. Appl. Environ. Microbiol. 69:7319-7327.

25. Nome, S. F., Raju, B. C., Goheen, A. C., Nyland, G., and Docampo, D. 1980. Enzymelinked immunosorbent assay for Pierce's disease bacteria in plant tissues. Phytopathology 70:746-749.

26. Purcell, A. H. 1980. Almond leaf scorch: leafhopper and spittlebug vectors. J. Econ. Entomol. 73:834-838

27. Purcell, A. H., and Saunders, S. R. 1999. Fate of Pierce's disease strains of Xylella fastidiosa in common riparian plants in California. Plant Dis. 83:825-830.

28. Purcell, A. H., Saunders, S. R., Hendson, M. Grebus, M. E., and Henry, M. J. 1999. Causal role of Xylella fastidiosa in oleander leaf scorch. Phytopathology 89:53-58.

29. Raju, B. C., Goheen, A. C., and Frazier, N. W. 1983. Occurrence of Pierce's disease bacteria in plants and vectors in California. Phytopathology 73:1309-1313.

30. Raju, B. C., Nome, S. F., Docampo, D. M., Goheen, A. C., Nyland, G., and Lowe, S. K. 1980. Alternative hosts of Pierce's disease of grapevines that occur adjacent to grape growing areas in California. Am. J. Enol. Vitic. 31:144-148.

31. Raju, B. C., and Wells, J. M. 1986. Plum leaf scald: isolation, culture, and pathogenicity of the causal agent. Phytopathology 72:14601466

32. Sorensen, J. T., and Gill, R. J. 1996. A range extension of Homalodisca coagulata (Say) (Hemiptera: Clypeorryncha: Cicadellidae) to southern California. Pan-Pac. Entomol. 72:160-161

33. Tyree, M. T., and Zimmerman, M. H. 1983. Xylem structure and the ascent of sap. Pages 89-94 in: Springer Series in Wood Science, 2nd ed. Springer-Verlag, Berlin

34. Wells, J. M., Raju, B. C., Hung, H. Y., Weisburg, W. G., Mandelco-Paul, L., and Brenner, D. J. 1987. Xylella fastidiosa new genus new species gram-negative xylem-limited fastidious plant bacteria related to Xanthomonas spp. Int. J. Syst. Bacteriol. 37:136-143.

35. Wells, J. M., Raju, B. C., Nyland, G., and Lowe, S. K. 1981. Isolation, culture, and pathogenicity of the bacterium causing phony disease of peach. Phytopathology 73:859-862.

36. Wistrom, C., and Purcell, A. H. 2005. The fate of Xylella fastidiosa in vineyard weeds and other alternate hosts in California. Plant Dis. 89:994-999. 